\title{
Dynamic Design: The Structure of Books of Poems
}

How should a book of poems be organized, and in what ways does it matter? How have poets shaped their books and what are the effects of those shapes? Because a collection of poems is sequential, not simultaneous like visual art, and even though many readers don't read the poems in order, understanding a book's design is a way to deepen one's experience of the book. I like the idea of gesture (Latin, to carry) as a trope for a book's organization: How does the book carry itself, and how does it move the reader? While many poets do this intuitively, and readers are highly disparate in their practices, I would like to try to make these principles explicit. In other words, I will ask how organization can provide a richer, more "writerly" (to use Roland Barthes' term) experience for the reader.

Poets have always structured their books of poems, Neil Fraistat points out in Poems in their Place; Ovid, Horace, Petrarch, Virgil, Milton, Pope, Dickinson, Whitman, and Yeats were among those known to have paid attention to what Fraistat terms "contexture": "the contextuality provided for each poem by the larger frame within which it is placed, the intertextuality among poems so placed, and the resultant texture of resonance and meanings" (3). Robert Frost, C.P. Cavafy, Adelaide Crapsey, and Wallace Stevens are modern poets whose collections' contextuality revealed new insights about their work. In the case of Sylvia Plath's Ariel, Marjorie Perloff shows that the book organized by Ted Hughes emphasizes death and self destruction, while the book as originally organized by Plath reveals her outrage at Hughes' adultery. Looking at Edgar Lee Masters' Spoon River Anthology, John Berryman's Dream Songs, and Robert Lowell's Life Studies, among others, M.L. Rosenthal and Sally Gall argue that the modern poetic sequence "fulfills the need for encompassment of disparate and often powerfully opposed tonalities and energies" (3) through a "liberated lyrical structure" (11).

One might draw upon Roland Barthes' notions of writerly and readerly texts to understand how structure complicates meaning: has the poet created a text that allows the reader maximum possibility? Barthes insists, "the goal of literary work (of literature as 
work) is to make the reader no longer a consumer, but a producer of the text" $\left(S / Z_{4}\right)$. Writerly texts allow "entrances, the opening of networks, the infinity of languages" ( $\left.S / Z_{5}\right)$. Barthes uses analogous terms in The Pleasure of the Text, the text of pleasure and the text of bliss. Experienced readers want poems to make them work harder, equating that work with bliss. For Barthes, the text of pleasure "contents, fills, grants euphoria; comes from culture and does not break with it, is linked to a comfortable practice of reading," but the text of bliss is "the text that imposes a state of loss, the text that discomforts," that "unsettles the reader's historical, cultural, psychological assumptions... [and] brings to a crisis his relation with language" (Pleasure 14). If the text of pleasure is a marriage, then the text of bliss gestures like a lover.

The terms readerly/pleasure and writerly/bliss are often taken as synonyms for "conventional/classical" and "experimental/avant garde" but it is important to note that the latter category is created by the reader. "The writerly text is not a thing," Barthes points out (S/Z 5) but a "perpetual present"; criticism treats texts of pleasure, while bliss is beyond words. Thus his terms do not signify binary oppositions between easy and difficult or mainstream and avant garde. The writerly text cannot be found in the bookstore $(S / Z 5)$, but is rather a process of reading, a questioning of convention. Barthes' provocative ideas emphasize the ineffability of the reader's production of the text, and its personal, even onanistic nature.

In the essay that follows, I trace my reading of conventions that apply to the structure of books of poetry in an attempt to discover how they carry me over the threshold (or not) into bliss. I outline these conventions-writerly gestures, as it were, contained in readerly texts-with the hope that readers will subsequently be more alert to them, more able to construct their own bliss in the books of poems on their shelves, or if they are poets themselves, to think about these gestures when putting together their next book. Since my aim is to convey the range of principles of organization, my treatment of them is necessarily glancing.

The beginning of a book tells the reader a great deal about what will follow. With what gestures do poets welcome readers into their worlds? Opening strategies can seize the reader's attention, enacting a sense of mystery or anticipation, beginning, dawn, birth, or creation, signaling the book as the new thing that it is. 
For example, Veronica Patterson begins Swan, What Shores? with a poem that ends, "Sometimes, unguarded, you fall asleep," suggesting that what follows is the unguarded product of a dream world. Carl Phillips begins Cortège with "The Compass," a poem that ends, "what is lovely an arrow," pointing to the following poems. Although the first poem is usually a shorter poem, an appetizer, exceptions in books by Campbell McGrath, Carolyn Forché, and Heather McHugh, among others, signal the poet's seriousness and ambition and imply that the reader is hungry enough to begin a main course without prelude.

The autobiographical strategy introduces the speaker to the reader, often opening the book as a narrative of the speaker's life. Beginning with a flashback in time to the speaker's parents as Sharon Olds does in "I Go Back to 1937" (The Gold Cell) signals her psychoanalytic interest in herself as a product of her parents. Martín Espada's "My Name Is Espada" (A Mayan Astronomer in Hell's Kitchen) takes a different spin on the autobiographical: he invokes the historical, etymological wordplay of his name, embracing an ethnic family larger than his two parents. The autobiographical gesture negotiates between self and subject; that is, the poet is never just a unique person speaking honestly about her individual life, but rather, someone subject to social codes such as class, race, nationality, and gender. Moreover, because the poet uses language, which is also subject to these codes, saying "I" is doubly vexed. No self is primary, untouched by culture-and poets acknowledge this to varying degrees.

Some autobiographical gestures remain deliberately oblique-in effect the poet says, don't expect this to be a memoir, "I" can't be contained in a poem. Sandra Alcosser begins Except by Nature with "My Number," a poem of twelve couplets that functions as a biography of an alter ego. The poet's number is "small. A hundred pounds of water." The speaker "wears her like a shadow" and they "judge each other." The poem ends, "Together we dance-my number and her best dresses." Using the term "number" to signify an alter ego plays against the infinite nature of personality which of course can't be summed up with mere numbers. Yet the poet's number-which can be made concrete in language-is also the book that follows, in a dance with the reader. Lucie BrockBroido's "Carrowmore" begins The Master Letters with an oblique 
autobiographical gesture: "Wherever I went I came with me.... My thick braid, my ornament-//My belonging I/Remember how cold I will be." These poets question the easy correlation of identity and biography, and create poetry as alternative autobiography, using convention but giving it a writerly turn. In other words, the "facts" may not be there, but poems, like fingerprints, still provide a sense of the poet's identity.

A version of the autobiographical gesture is a poem "about" seeing. In a sense, a book takes the reader on a tour of what the poet sees-or doesn't. Thus, poems about seeing often include disclaimers, presenting the problems of subjectivity, light, and point of view. Heather McHugh's "Spectacles," the first poem in her first book, Dangers, notes how subjective seeing is, that each of us sees what she wants to see. A pair of spectacles can be a "bright suggestion to the uncorrected/eye, or a small/wrecked bicycle." Robert Hass's "Heroic Smile" (the first poem of Praise) also combines point of view with a disclaimer. It begins: "A man and a woman walk from the movies/to the house in the silence of separate fidelities./There are limits to imagination." Similarly, Charles Wright opens Black Zodiac with "Apologia Pro Vita Sua," a poem that ends with the phrase: "more work to be done ..." a merging of the autobiographical with a disclaimer, a statement of the poet's insufficiency or inability. Harryette Mullen spoofs the convention of the disclaimer with the prose poem that opens Sleeping with the Dictionary, "All She Wrote," a list of excuses for not writing: "Forgive me. I'm no good at this. I can't write back. I never read your letter. I can't say I got your note.... If I couldn't get back to writing, I thought I'd catch up on my reading. Then Oprah came on with a fabulous author plugging her best-selling book." Since Oprah doesn't read poetry, and books of poems don't become best-sellers, Mullen is claiming other territory for her poetry; in fact, the prose list functions like a photographic negative of a customary opening poem.

Another way to begin a book of poems is with a prayer, often a gesture that emphasizes the individual speaker as part of a larger community. Poets Agha Shahid Ali, Jorie Graham, Grace Schulman, Tom Sleigh, and Connie Voisine, among others, begin books with this gesture, suggesting that the book of poems is a religious experience, for the poet and hopefully for the reader. Recalling the Bible and other holy texts, this gesture places the poet in a tradition of 
the mystic or spiritual visionary or humble supplicant. Of course, what the poet prays for varies-independence for Kashmir in the case of Shahid Ali, for instance, or peace between Arabs and Jews in the case of Schulman. The reader is assumed to be part of a community that cares about the poet's plea. Conversely, Heather McHugh's seventeen page long deathbed vigil, "Not a Prayer," opens The Father of the Predicaments with a gesture of individual mourning.

Calling attention to the genre of poetry itself with an ars poetica is an opening gesture which places the poet among his (usually male) peers, and sometimes ironically. For instance, Mark Strand's list poem,"The New Poetry Handbook" in Darker ("If a man understands a poem, he shall have troubles") creates a "club" for poets, making the male reader an honorary member, and Gabriel Gudding's "A Defense of Poetry" opens his book of the same title with a nod to Philip Sidney's "Defence of Poesie" and Percy Shelley's "A Defence of Poetry." Gudding's poem takes the form of numbered prose statements, like Christopher Smart's "Jubilate Agno," about his cat Jeoffrey. Unlike Smart who was actually confined to a madhouse, Gudding's speaker feigns madness, addressing a reader who has "the mental capacity of the Anchovy" and incorporating "discomfiting" references to bodily grossness. These gestures foreground the genre, perhaps compensating for the fact that poetry is not widely read, and that poets are not well known, something that would especially matter to male writers whose status in the culture can be diminished by writing poetry. Another way to invite the reader to think about art and convention is to begin with a poem about another art wherein the reader reads "poetry." Robert Hass's "Spring Drawing" (Human Wishes) and Seamus Heaney's "The Rain Stick" (The Spirit Level): "Who cares if all the music that transpires// Is the all of grit or dry seeds through a cactus?/ You are a rich man entering heaven/Through the ear of a raindrop. Listen now again," are examples. A broader-and much employed-version of the ars poetica is the poem about language.

"Part," the first poem in Phillis Levin's book, Mercury, combines several of these gestures. It is part personal poem of loss, part disclaimer, and part language poem. As an extended definition of "part" it serves to remind the reader that a poem (and a book of poems) are only pieces of a poet's work and self: "Of something, 
separate, not/Whole; a role, something to play/While one is separate or parting."

The use of fragments and enjambed lines underscores the reader's partial story, and the last line's inversion-which leaves it without a period-asks the reader to supply the missing last word, "part":

Take from, sever, as in

Lord, part me from him,

I cannot bear to ever

Parallel to a discussion of openings is a discussion of endings. What is the book's trajectory? How does the ending connect to the beginning? In the same way that a poem's ending holds the key to its interpretation, the last poem in a book underscores its meaning emphatically. Teleology is the study of endings, which ideally should seem inevitable from the beginning. Does the book click shut or hang in the air, dissolve or fly away? Whatever tone it adopts, the last poem must conclude. The same gestures apply for endings as for beginnings. For instance, Mark Doty begins and ends Source with an ars poetica. Some endings are self-conscious, for instance Billy Collins' "Some Final Words" in The Art of Drowning (an analogue to his opening poem, "Dear Reader"). Some books use a period of time as container and close with a poem about night; others return to some aspect of the opening gesture as a way of creating the book's wholeness. One of the most unusual instances of this is Linda McCarriston's Eva Mary, which begins and ends with the same poem, "The Apple Tree." Of course, after the intervening poems about domestic abuse and violence, the apple tree becomes a symbol of the fallen world. In David Baker's Changeable Thunder, clouds are the subject of the first and last poems, but the first poem is historical while the last poem personalizes clouds, almost as if the reader has earned this intimacy.

The idea of closure meets with some resistance in postmodern poetry, which may show an antipathy to fixed meaning. Barbara Hernnstein Smith points out that "anti-closure is a recognizable impulse in all contemporary art, and at its furthest reaches it reflects changing presumptions concerning the nature of art itself" (238). Anti-teleological art correlates with modern philosophy via an unfinished quality that suggests possibility, openness, continuation, 
an inability to determine endings, and skepticism. In the postmodern world, "conviction is seen as self delusion and all last words are lies, the only resolution may be in the affirmation of irresolution, and conclusiveness may be seen as not only less honest but less stable than inconclusiveness" (Hernnstein Smith 241).

Lyn Hejinian puts her resistance to closure another way: "I perceive the world as vast and overwhelming; each moment stands under an enormous vertical and horizontal pressure of information, potent with ambiguity, meaning-full, unfixed, and certainly incomplete. What saves this from becoming a vast undifferentiated mass of date and situation is one's ability to make distinctions. Each written text may act as a distinction, may be a distinction. The experience of feeling overwhelmed by undifferentiated material is like claustrophobia. One feels panicky, closed in. The open text is one which both acknowledges the vastness of the world and is formally differentiating. It is the form that opens it, in that case" (653).

Yet because poetry uses language and language is structural, poets can't not end their poems or their books, so the effect of anticlosure is subtle. Online poetry is an exception, for example by creating an endless loop that doesn't permit the reader to get out, or by providing alternative endings. For instance, Stephanie Strickland's vniverse.com demands more flexible reading than a traditional text. Some readers, unused to having their choices made so explicit, may find the poem more difficult or time consuming than a page-bound series of poems, yet this may well be the future of reading, and it certainly fulfills Roland Barthes' wish for a writerly text, one that the reader produces.

Asking contemporary poets how they begin the process of ordering their books produces a surprisingly uniform group of answers. Some principles of structure are balance and contrast; dynamic energy; surprise; breathing space/white space; a dialogue between intent and serendipity, or in Annie Finch's words, between "tension and inevitability" (Heginbotham 113). Elaine Terranova writes: "For me putting a manuscript together is a reductive process, somewhat the way I write a poem. I'm always flinging poems aside, once I'm convinced that they 'do not get along well with the others.' The chosen poems form some sort of association. I'm looking for something that fits together organically, like a poem, just as in a poem I search for the lines that adhere. I feel a book should have distinct openings 
and closings. I'd begin with a poem about fresh starts, beginnings, mornings. Something that heralds the theme of the collection, something I'm setting out to prove. I remember how we'd pick a photo for a front page of the little newspaper I once worked for, that faced right, looking in to the rest of the paper." Alicia Ostriker puts a book together when she has more poems than necessary for a book-length collection: "The floor gets covered with poems grouped into various categories, regrouped, sequenced, exchanged with each other; the order shifts and reshifts, the sections of the book form and change places" (Heginbotham 113).

As Terranova points out, heuristics for organizing a manuscript can come from other genres. Poets can use film conventions to talk about movement: poems can make jump cuts and use flashbacks, for instance, or develop a character, like Mary Jo Bang's Louise in Love. Another strategy is to move from the specific to general or the general to the specific-does the book turn from a microscope to a telescope or vice versa? Susan Stewart's The Forest is divided into two parts, the first using personal and family material, and the second broadening or globalizing these concerns. Perhaps because I was teaching so much composition at the time, the strategy I used in my first book, Red Under the Skin, was rhetorical, grouping the poems around three questions probably not apparent to a reader: how are we written upon? what can we do about it? how do we write back?

Along with questioning beginnings and endings, and the movement between them, the reader can ask how poems are grouped to create gestures. The way the end of one poem slides into or contrasts with the beginning of the next creates an associational order. These transitions can be thought of in terms of sequence, time, comparison, contrast, example, cause and effect, place, concession, summary, and repetition. For example, in Molly McQuade's Barbarism, the poem "Furtive and Fiery" ends with the line "in deciduous caves" while the next poem begins, "When a bear comes out at last into the woods." The transition is created by place: although the first poem mentions caves, it is not about bears, and the second poem elides the word "cave"; thus the space between the two poems creates the reader's momentary cave.

One of the most amusing ways of ordering a book is an abecedarius, where the poems are arranged alphabetically by title, as in 
Sharon Bryan's Flying Blind; Edward Kleinschmidt Mayes' Works and Days; Barbara Greenberg's The Spoils of August; Susan Stewart's Columbarium; and Harryette Mullen's Sleeping with the Dictionary. Other poets use an abecedarius as an organizing principle for a section of their book, for instance Barbara Hamby's The Alphabet of Desire. Although arrangement by alphabet is as old as the Psalms, its incarnation in contemporary poetry is postmodern, emphasizing randomness by allowing language rather than theme to dominate. In other words, if the poet arranges the poems alphabetically after they have all been titled, then the order is not dictated by content (although of course one could cheat and change titles to make the poems fit a secondary scheme). Another way of ordering "randomly" is to use the I Ching (or to throw the poems down a flight of stairs?) to find mysterious and previously hidden resonances. I have yet to find someone who admits to doing this, but why not? Because it is our habit to assume deliberation, as Stanley Fish notes in "Is There a Text in This Class?" the reader of such a random text would still find order. In other words, when one is primed to make meaning and see structure, one will. One might assume a flawed order, but not that there's no order. As Barbara Hernnstein Smith notes, "in games we 'play' with chance, in art we control chance" (262). Yet another way of acknowledging chance is to order a book chronologically, by the date individual poems were written. Charles Wright admits to this method, saying "I know this is an odd process, but I have been doing it for years" (Heginbotham, "Whatever" 271). Although in most cases the reader has no way of knowing that chronology is the organizing principle, sometimes it suggests an embedded narrative of self; in other words, as the poet grows and changes, so do the poems.

Poets sometimes write poems that adhere to particular groupings, thematic or formal, and then must decide whether to keep "groups" of like poems together or mix them up. The poet arranges the furniture of her house, deciding whether the experience needs clarification or complication. Recognizing poems grouped by theme and subject is easy because we are used to such groupings, in grocery stores, for example. The danger is that the reader might become bored, expecting every poem in that group to be "about" family or jazz or food, and that the juxtapositions do not create energy. Readers expect to see a bed in the bedroom, while a bed in the kitchen can 
surprise. Poems grouped by theme should differ in other ways, in form or in tone, and serve the book as a whole. In addition to the groupings themselves, sometimes marked by Roman numerals, the poet can offer another heuristic-that of section titles-which also must be held up to the same criterion as the rest of the book: does the section title highlight something that otherwise would be overlooked? The problem with such pointing is that titles can be too much wordage, insulting the reader's intelligence, akin to providing endnotes for already obvious information. Numbering the sections emphasizes sequence more than other kinds of markers, for instance asterisks. Dividing a book into sections is analogous to the division of an hour into quarters, a symphony into movements, a harmony into parts; such divisions should make the experience more artful, not merely more clear.

A book that keeps groups of poems together is R.T. Smith's Trespasser; Ireland is the primary subject, but "Trespassing" with its etymology of "crossing" refers at once to the poet in a foreign land and the sins of humanity. Smith's book is divided into two sections: the first, "Uisce Beatha" (literally, "water of life" but colloquially, "whiskey"), is composed of twenty-six poems of daily life. The second, "Gristle," contains eleven poems of the miraculous, a series akin to Seamus Heaney's "Sweeney" poems. "Gristle" is cartilage, the substance that remains once the meat falls away, but also, Smith tells us, St. Gristle, a "shunned monk/ shocked by Druid dolmens" whose church consists of "crickets, whin, and owl bones." Smith's decision to group the "Gristle" poems together was the right one, because these poems are already so varied within themselves (in voice and subject) that reading them together magnifies the pagan world they create. If he had sprinkled them throughout he would not have created the strong effect of ending the entire book with this group of poems; ending with the "Gristle" poems makes the reader question the traditions and conventions detailed in the first section. The "Gristle" poems seem to say that there is way out, a way through the imagination. Moreover, this smaller group suggests the lack of balance between the "real" and the "unreal," with the former being given considerably more space, but the latter being given the "last word."

A book that mixes groups is C.D. Wright's Tremble, constructed in a way that keeps the reader wondering what will come next. 
Tremble features thirty-six poems without subsections, appropriate for a short book of love poems. Wright sprinkles six "Girl Friend" poems - each dedicated to a different woman-throughout. The first is simply titled "Girl Friend," and it exemplifies Wright's gift for making her syntax surprising, and plumbing the possibilities of poetry by making the reader work in the white space. Following "Girl Friend" with a poem titled, "And It Came to Pass" suggests that a community of voices and relationships provides the answer to the nature of "something else out there." The book closes with "Girl Friend Poem \#6":

When I snap my fingers

You will wake in a dear yet unfamiliar place

You will scarcely remember your travail

You will be eating green caterpillars over a small fire

An awesome congeries of youthful men and women

Will be brushing these very tracks away.

This poem exemplifies Wright's gift for inviting the reader into her life: the addressee is Debbie, but also the reader, whom the poet wakes out of the hypnotic state of reading into the world. The poem ends the volume with a note of generosity and lightness, intimacy and otherworldliness, and Wright's attention to the nuance of sequence makes Tremble a construct of dynamic energy.

Wright does not append a list of explanatory or bibliographic notes. Quite a few contemporary books of poems do, in what I would argue is a "readerly" gesture. T.S. Eliot may have started the trend, appending notes to The Waste Land that Richard Badenhausen points out "seem to exclude the amateur unschooled in the proper use of such scholarly apparatuses" (76). Vladimir Nabokov's novel Pale Fire spoofed notes by giving them a life of their own, Paul Fournel wrote a novel composed entirely of footnotes, and some contemporary poets have also put pressure on the convention, for example Jenny Boully. However, the notes of most contemporary poets seem motivated by a desire to appear well read or to save the reader trouble, and/or to dictate the reading of the particular poem. For instance, Adrienne Rich's "Six Narratives," in Dark Fields of the Republic, Poems 1991-1995, includes a note that says the narratives are spoken in different voices, information that could have been includ- 
ed in the title, signaled by the poems themselves, or simply left to the reader to decide. In the note to "Prayer" in Never, Jorie Graham writes, "I take my poem to be in conversation with such notion of the gods-and of how history transforms them-as is put forth in Herbert's poem. In attempting to enact a realistic description of metamorphosis, 'Prayer' wonders, among other things, what the 'suitable' distance between subject and object, gods and humans, humans and nature, might be" (111). This example of a poet giving the critics a head start suggests an uneasiness that they won't get there without her, either because the poem's text is obscure or because the critics are dense. One might recall again Barthes' quest for the writerly text, not as a license for obscurity, or justification of difficulty for its own sake, but for the reader's bliss. A book of poems is a space of play, and endnotes close that space with a fence.

In a world where poems are more often than not read in anthologies, magazines, on the web and out of their original context, it's important to be reminded of the ways context can enhance one's reading experience. Reading a poem in an anthology is an air kiss, but reading it within the structure the poet has provided for it can be a thoroughly sexual encounter. For me Yusef Komunyakaa's Talking Dirty to the Gods epitomizes the writerly text. Indeed, its very project argues that language is a kind of sexual pleasure. The book contains 132 (the large number creates an orgy!) poems consisting of four four-line stanzas. The musical $4 / 4$ signature, or common time, provides a structural evenness that permits thematic wildness and rapid shifts in tone: like a commonplace book, Talking Dirty to the Gods is crammed with characters, notations, stories, odes, pleas, and rants that together suggest both the coarseness of human nature and the refinement of the poet's language. Some of the poems are rhymed and metered, others use accentual measures. The book is not divided into sections; rather, its poems sweep across the reader like waves, with time to come up for air only between poems. The first poem is "Hearsay," and the last is "Heresy": by that one missing letter, the poet signals the subversive power of his making, his rebellion against religion and the status quo:

No, it wasn't the penis

Pharisees wished abridged 
$\&$ amputated. That season

Tongues rotted like fat figs

On broken branches. Pelagian wit

Could cost a man his head.

Women were already banished

From the pulpit, \& their songs

Held only an after-scent of myrrh.

Some sculpted lies \& dripped gold

Into them. Others saw burning pyres

\& said Free Will couldn't live

In a doll's body, termites in the godhead.

Just as the Briton Pelagius dared to challenge the doctrine of original sin, the poet using his Anglo-Saxon tongue challenges the centrality of the Phallus. Faced with the rigid heterodoxy of religion, patriarchy, and language, some women subvert from within by "sculpt[ing] lies" and "drip[ping] gold into them." Others reject the paradigm entirely. In his last poem, the poet aligns himself with the female, evoking the Nietzschean parallel between subversion, art and the feminine-the poems themselves become "termites in the godhead," chewing away at the foundations of western society. This poem's dynamic blend of modesty (termites are small) and pride (they can take down houses) mirrors the book's strategy. 132 small poems can add up to a lot of destruction —and a lot of pleasure for the reader.

Books carry their readers lightly or ploddingly. Just as line or stanza breaks create energy and conflict in individual poems, surprising juxtapositions create energy and movement in a collection. Roland Barthes states that a text of bliss "granulates, crackles, caresses, grates, cuts, and comes," verbs of movement and friction. The poet must use convention, but not be used by it, in order to create a free flow of energy through the book, clearing clutter and making the space inviting, yet not dictating the path so much that the reader cannot reenter with a sense of discovery. Poets who trust their readers make their book's structure a partnership, an invitation to find bliss. 
Alkalay-Gut, Karen. "Death, Order, and Poetry: 'The 'Presentation Copy' of Adelaide Crapsey." American Literature 57 (2) (May 1985): 263-289.

Badenhausen, Richard. T. S. Eliot and the Art of Collaboration. Cambridge: Cambridge University Press, 2005.

Barthes, Roland. S/Z. Trans. Richard Miller. Preface by Richard Howard. New York: Hill \& Wang, 1974.

. The Pleasure of the Text. Trans. Richard Miller. New York: Hill \& Wang, 1975.

Bevis, William W. "The Arrangement of Harmonium." ELH 37 (3) (Sept 1970): 456-473.

Fish, Stanley. Is There a Text in This Class? The Authority of Interpretive Communities. Cambridge: Harvard University Press, 1982.

Fraistat, Neil, ed. Poems in Their Place: The Intertextuality and Order of Poetic Collections. Chapel Hill: University of North Carolina Press, 1986.

Heginbotham, Eleanor Elson. Reading the Fascicles of Emily Dickinson. Columbus: Ohio State University Press, 2003.

. "Whatever it is, she has tried it': Contemporary Poets on Editing—and Dickinson's Fascicles." Emily Dickinson at Home. Proceedings of the Third International Conference of the Emily Dickinson International Society. Ed. Gudrun M. Grabher and Martina Antretter. Trier: WVT Wissenschaftlicher Verlag, 2001.

Hejinian, Lyn, "Against Closure," in Paul Hoover, ed. Postmodern Poetry: A Norton Anthology. New York: W.W. Norton, 1994.

Herrnstein-Smith, Barbara. Poetic Closure: A Study of How Poems End. Chicago: University of Chicago Press, 1971.

Paschalis, Michael. "Thematic Collections and Generation of Meaning in Cavafy's Poetry." Journal of Modern Greek Studies 17 (1999): 403-412.

Perloff, Marjorie. "The Two Ariels: The (Re)Making of the Sylvia Plath Canon." In Neil Fraistat, Poems in Their Place, 308-334.

Rosenthal, M.L. and Sally Gall. The Modern Poetic Sequence: The Genius of Modern Poetry. New York: Oxford University Press, 1983.

Terranova, Elaine. Correspondance with Natasha Sajé. June 2003. 